\title{
Henriette Roos John Miles - terug uit die buiteveld
}

Henriette Roos is 'n professor in Afrikaanse Letterkunde aan die Universiteit van Suid-Afrika, Pretoria. E-pos: rooshm@unisa.ac.za

Die eerste literêre debat van die nuwe jaar het die onsekere toekoms van die Afrikaanse letterkunde as tema gehad, en Die Buiteveld (2003), die jongste roman van John Miles, is direk hierby betrek. Joan Hambidge (2004: 14) verwys na resensente se oorwegend "louwarm ontvangs" van hierdie eerste Miles-roman wat in meer as 'n dekade verskyn het, en interpreteer dié reaksie as teken van lesers se misnoeë met 'n verskraling in die kwantiteit en kwaliteit van Afrikaanse publikasies vandag. In sy "repliek" op Hambidge, verswyg Dan Roodt (2004: 17) Die Buiteveld in alle tale, moontlik omdat die strekking daarvan nie sy argument ondersteun dat hedendaagse skrywers "doodbang is om iets te skryf wat dalk nie politiek korrek kan wees nie". Daar word wel skuinsweg in Miles se rigting geskimp as Roodt skryf van "akademici, soos aan Wits, (wat) hulle eie departement doodgemaak" het. Miles, tot met sy aftrede hoof van die Departement Afrikaans aan die Universiteit van die Witwatersrand, het klaarblyklik met Die Buiteveld weer die speelveld van die Afrikaanse romanwêreld betree. En die impak van daardie teenwoordigheid is sigbaar in die ongemak van resensente, die wye publisiteit in koerante en tydskrifartikels en die keuse van die roman as een van die lystrekkers van 'n belangrike boekwinkelgroep. Maar deur sy lang randverblyf het Miles ook vir meer as een generasie jong lesers, grootgeword in 'n kitskultuur van eendagswonders waarbinne meedoënlose mediablootstelling die belangrikste vereiste $\operatorname{vir}(\mathrm{h})$ erkenning is, 'n minder bekende naam geword. As jy gelukkig is, kan jy die destyds opspraakwekkende en veelbekroonde Kroniek uit die doofpot (1991) as 'n voorgeskrewe werk op universiteit leer ken; indien nie, is die outeur en sy oeuvre tot die geskiedenis van die Afrikaanse letterkunde teruggeskuif.

Die verskyning van Die Buiteveld in Oktober 2003 het saamgegaan met'n - vir John Miles heeltemal nuwe - publisiteitsveld tog van openbare verskynings en onderhoude. Aan ou lesers het dit die geleentheid 
gebied om vanuit'n nie slegs streng tekstuele perspektief opnuut insig in die besondere werk van hierdie outeur te kry; die nuwe leser kon kennismaak met iemand wat in verskeie opsigte innoveerder en spilfiguur van die Afrikaanse roman is. 'n Gesprek met Miles rondom Die Buiteveld word in hierdie opstel weergegee; as inleiding word met die oog op daardie nuwe lesers -'n kort oorskou van sy skryfkuns gegee (sien Roos, 1998: 80, 82, 99).

\section{Literêr-historiese oorsig}

John Miles debuteer in 1970 met die kortverhaalbundel Liefs nie op straat nie, waarna die romans Okker bestel twee toebroodjies (1973), Donderdag of Woensdag (1978), Stanley Bekker en die boikot (1980), Blaaskans (1983) en Kroniek uit die doofpot (1991) volg. Kannemeyer (1988: 379-381) meen dat Miles se werk ten spyte van die integrasie van "alledaagse dagbladmateriaal (...) spanningsvolle beweeglikheid (...) (en) (...)'n ironiese perspektief, (...) te sterk draers van 'n ideologie" is. Indien die uitbeelding van individuele weerloosheid in die sig van alles-deursyferende en totaal korrupte magstrukture as' $n$ ideologiese obsessie beskou kan word, is dit wel so dat Miles se vertellings uiteindelik almal dieselfde verhaal vertel. Sy prosa word ook deur sowel Elize Botha as Kannemeyer met "huiweringswekkende en koelbloedige wreedheid" verbind, hoewel die kontesterende aard van sy oeuvre so sterk is dat die geweldmotief nie as die primêre fokus daarvan uitgewys kan word nie. Kontestering, opstand, rebellie; motiewe wat in die konteks van die sewentigerjare boweal verband hou met die stryd vir individuele regte en waardigheid binne die destydse apartheidbestel.

Miles se werk kan ten opsigte van tema en styl egter moeilik by enige bepaalde groepering of tendens ingedeel word en dit lees dikwels opvallend innoverend en "vreemd". Met Liefs nie op straat nie word'n hele nuwe era in die Afrikaanse letterkunde ingelui, naamlik die fase waartydens die kortverhaal(bundel) as prosagenre op die voorgrond tree. Dit wat die eerste keer by Miles voorgekom het - die abrupte verteltoon, die afsydige vertellershouding, die byna filmiese beskrywings, die motiewe van geweld en magsmisbruik-sou daarna weer en weer deur'n nuwe generasie skrywers nagevolg word. Sy klem op die (voor)stedelike landskap kan die leser vandag terugvind in die werk van Jaco Fouché, Herman Wasserman en Tom Dreyer, veral ook in die gewelddadige toonaard van Dreyer se vertellings. Donderdag of Woensdag (op aanbeveling van die Publikasieraad verbied in 1978, soos wat ook later gebeur met die "kinderboek" Stanley Bekker en die boikot) is wel'n 
uitnemende manifestasie van littérature engagée; 'n postmodernistiese roman met' $n$ komplekse en digte teksstruktuur waarin direkte toespelings op Suid-Afrikaanse realiteite, ' $n$ byna surrealistiese spel van tye en ruimtes en toespelings op klassieke en literêre verbande funksioneel verweef word. Roodt (1988: 53-60) verwys onder die noemer "postmodernisme" na'n hele aantal tekste wat volgens hom sedert die begin van die sewentigerjare die modernistiese Sestiger-tendens "indien nie uitvee nie, ten minste binne parentese plaas". Een van die outeurs wat hy voor in die ry plaas, is John Miles. In Blaaskans: die bewegings van Flip Nel vind 'n verstommende en meevoerende transformasie van historiese feite, aktuele realiteit en romantiese verhaalkonvensies binne' $n$ bedrieglike, byna ondermynende verhaalwêreld plaas. In hierdie boeiende verhaal, sekerlik een van die heel eerste van die nuwe historiese romans wat die Afrikaanse prosa vanaf die negentigerjare sou kenmerk, lei die vertelstruktuur tot' $n$ formulering van die aktuele problematiek en' $n$ besinning oor hoe daardie probleme hanteer kan word;'n vorm van eietydse geskiedskrywing. Die veelbekroonde roman Kroniek uit die doofpot rekonstrueer uit bestaande polisiedossiers' $n$ individuele geval van polisiebetrokkenheid by politieke moord. Dit is'n merkwaardige metafiksionele teks wat struktureel en ideologies van die bekendste Afrikaanse en eeue-oue Afrika- en Europese literêre tradisies ontgin.

\section{Wat het die afgelope dekade gebeur? ${ }^{1}$}

Die stilswye na die verskyning van Kroniek uit die doofpot gaan saam met veranderde persoonlike en professionele omstandighede. Miles het tydens sy laaste (verlof)jaar by Wits gewerk aan 'n roman voordat hy uit Johannesburg verhuis het na 'n plaas by Nieuwoudtville waar hy toe in ' $n$ tent gaan bly het terwyl hy besig was om huis te bou. Met die skoonmaak van sy tafel en boeke uitpak kyk hy toe weer na die aanvoorwerk vir die nuwe roman en kom agter hoe langtand hy daaroor was. Dit was ' $n$ verhaal gesitueer in Johannesburg; 'n soort stads/huisroman wat munisipale politiek betrek: ' $n$ pad gaan hier gebou word en ' $n$ huis gaan platgeslaan word. Maar dit sou ook' $n$ verhaal moes word van die konflik tussen die private lewe en dit wat' $n$ groep van jou verwag - 'n appèl wat aan jou gerig word en waardeur die persoonlike belange en dié van die groep in botsing kom.

Hierdie besigwees met die stadswêreld het Miles eenkant gelos toe ' $n$ nuwe kwessie hom begin interesseer het. "Ek is in dié tyd geraak deur die jongste vorm van die verstrooiing onder ons mense - ' $n$ mens dink dat met 'n nuwe grondwet en nuwe demokrasie en'n nuwe nasie en 'n nuwe eenheid 
is almal gelukkig - wat is die probleem? Maar tog is daar derduisende mense wat die land verlaat met verskillende redes vir die weggaan. Hier het ek begin: met ' $n$ karakter met ' $n$ spesifieke houding en 'n spesifieke agtergrond - 'n ordentlike een!"

Miles meen dat die "verstrooiing" waarvan hy praat, tipies is van die Suid-Afrikaanse geskiedenis. Die sporadiese bewegings die binneland in deur die trekboere van die laat agtiende eeu en die meer georganiseerde trekke rondom 1836, die uitdryf en uitwissing van die Khoi-bestaan, en ná die Anglo-Boereoorlog die klein groepies wat padgee Argentinië toe, Angola toe, is bewys daarvan. Tydens die apartheidsjare was daar natuurlik die stroom swart vegters en bannelinge en enkele wit dienspligontduikers. Terselfdertyd was daar die geestelike migrasie van Afrikaans na Engels by baie mense wat Afrikaans as moedertaal leer ken het, maar dit weens ideologiese redes as gebruikstaal verwerp het. "Ek plaas my karakter teen die agtergrond van die groot verstrooiing van Afrikaanssprekendes sedert die negentigerjare. Tog bly Smerski uniek. Hy kry 'n ander naam en hy moet sy identiteit vind in 'n vreemde situasie - Smerski die woordeboekmaker. Geleidelik word sy lewe 'n soort buiteveld-bestaan: hy is nie meer so jonk nie; 'n man van so amper veertig, maar hy word dan in ' $n$ situasie geplaas waar hy oor sy lewe en sy verlede standpunt moet inneem".

\section{Die landskap van die verhaal}

Die situering van die verhaal in Portugal, en veral die noordelike dele van die bergagtige grens met Spanje, is ' $n$ nuwe landskap in die Afrikaanse roman. Gesien die talle ooreenkomste en verbintenisse tussen die twee gebiede, kan ' $n$ mens Portugal byna as ' $n$ verlengstuk van Suidelike Afrika beskou. Daar is die gedeelde koloniale geskiedenis, die padgee na Brasilië van hulle dienspligontduikers, die bloedlose revolusie van 1974, en na die onafhanklikheid die meer as ' $n$ miljoen mense wat terugkom na Portugal. Synde ' $n$ Afrikaanse mens, is Smerski ook baie bewus daarvan dat die Portugese eintlik die paria's van die Europese nasies is; dié wat met minagting bejeën en waaroor grappies vertel word. Een van die eerste vrae wat Smerski moet beantwoord wanneer hy lsabel ontmoet, is hoekom hy Portugal toe wou gaan en nie na Engeland nie. "Dít is die rede waarom ek Portugal (as verhaalruimte) gekies het".

Daar is talle verrassende, direkte koppelinge met Suid-Afrika wat in die verhaal voorkom. Baie veelseggend is byvoorbeeld die woorde van Da Gama se kroniekskrywer, Velho. ${ }^{2}$ Dat "assegaai" 'n woord is wat reeds in heel vroeë Portugese geskrifte voorgekom het, en dat Boerekrygsgevangenes in Portugal aangehou is, is dalk minder bekende skakels. 
Miles sê: "ek het toevallig in hierdie tyd baie gelees, onder andere Ferreira se boek (Ferreira O.J.O. Viva os Boers!: Boeregeïnterneerdes in Portugal tydens die Anglo-Boereoorlog, 1899-1902, 1994), en toe gee ek sommer vir Isabel so 'n hibridiese agtergrond omdat sy 'n onverstandige meisiekind is en sy kry dit dalk van hier".

Wanneer Smerski van Isabel praat as sy "boeremeisie", versterk dit vir baie lesers die koppeling Portugal/Afrika; die band draai dus nie alleen om groter kwessies soos kolonialisme en 'n diaspora nie, maar om feitelike, soms persoonlike skakels.

\section{Opstand, sonde en skuld}

Volgens Miles groei ook die opstandsmotief uit so 'n konkrete band. Die lewe van Isabel se Oupa is op histories korrekte feite gebaseer: die groep krygsgevangenes in Portugal was geweldig ontsteld oor die bevelvoerder wat so gou oorgegee het. Isabel se voorsaat was 'n Nel; toevallig het daar ook werklik'n Nel na Suid-Afrika teruggekom met sy Portugese vrou - sy is toe later hier dood - en daar was heelwat ander Nels ook. Daar was ook krygsgevangenes wat ontsnap het Nederland toe. In Portugal is hulle nie aangehou in 'n kamp nie maar moes net eenmaal per dag rapporteer. "Die opstandmotief wat deur die hele verhaal loop kon ek ook op hierdie manier aanroer. Smerski self is al heel aan die begin baie krities oor groepsdruk en die daarmee gepaardgaande openbare ritueel. Voor hy sy bakkie in Ponte de Lima gaan koop, sê hy vir sy vriend/kollega hy wil net nie daarheen gaan op die naweek wat die gewonde koei deur die strate gejaag word nie. Die depressie sal dan in vragte op hom neerdaal, want hy rig hom op teen die voorskriftelikheid van die openbare ritueel. In September 2001 was ons twee weke Portugal toe en het ek die ding visueel aanmekaar gesit en ek kom op 'n dag af op hierdie strafpale. 'n Pragtige voorbeeld daarvan is in Bragança net buite die fort op ' $n$ klein pleintjie die middeleeuse plek van straf. Daar was ook'n tentoonstelling in Bragança gewees van waterverfskilderye van die verskillende dorpies se strafpale. Hulle lyk nie almal dieselfde nie en is gemaak volgens verskillende style, maar almal is duidelik herkenbaar as pelourinhos. Ons kom toe op ' $n$ stadium naby die kus in die Minho-provinsie af op 'n dorp en daar staan 'n strafpaal met die jaar 1652! Dié Elena, wat ek sien as 'n teenpool van Isabel, vra/sê onmiddellik dat sy weet waarom Smerski belangstel in die goed en hy is geïrriteerd met haar houding. Asof sy heeltemal buite die kwessie van sonde en straf staan. Vandag weet ons dat in 'n geglobaliseerde wêreld niemand buite daardie ervarings staan nie. Hy sê vir haar 'hoekom ek en nie jy nie?' En hy sou kon byvoeg: 'Jy is mos 'n Duitser'. In die eerste 
kritiek op die roman wat ek gesien het, word daardie reaksie gesien as 'n poging tot relativering, maar vir my is dit nie so nie".

Miles beskou die skuldmotief vanuit ' $n$ historiese visie wat die beeld van 'n palimpses oproep. "Smerski sê dat ou verhale speel binne/deur ons hoewel hulle nooit presies soos in die klassieke vorm voorkom nie. Hy is die verlore seun, kom by die huis en daar is nie ' $n$ pa of ma nie, slegs ' $n$ stiefsuster met wie hy darem 'n goeie verhouding het, en hy is so verlig: hy en sy pa is nie op dieselfde vrou verlief nie maar net hy op sy baas se vrou! Naby die slot as hy op die strand stap, dink hy aan die verskillende fases in die geskiedenis van Portugal; die More en die Kelte en die Romeine, en elkeen maak ' $n$ bydrae tot die ontwikkeling van die land. Dié soort visie van 'n sikliese gang van die geskiedenis word meestal gesien as reaksionêr. Hoe dan ook, dis die sikliese wat Smerski opval tydens sy reis en dis wat ek waarneem wanneer ek Europa besoek en die uitgrawings sien, veral by die kerke. Soos in Lissabon se groot katedraal; in die klooster se suilegang, is hulle besig met opgrawings en 'n mens sien die spore van 'n ou moskee waar die kerk se fondamente tans is ... Ek speel dus met die gedagte dat vandag se slagoffer dalk more ' $n$ tiran is, of andersom".

\section{Die belydenis van skuld?}

Die kwessie van die konflik tussen persoonlike oortuiging en die openbare belang het Miles genoem as 'n kernmotief van daardie vroeëre, nog onvoltooide roman, maar dié tema betrek ook aspekte van die kritiek wat op Die Buiteveld gelewer is en het in verskeie koerantberigte na die publikasie daarvan aandag getrek. Die persepsie is geskep dat Miles met hierdie roman sterk standpunt inneem teen die doelstellings van die Waarheids- en versoeningskommissie - om deur kollektiewe skulderkenning 'n kollektiewe amnestie en nasionale versoening te bewerkstellig - en daardeur ook aweregs van die belangrike tendense in die resente Afrikaanse prosa en van sy eie vroeëre werke beweeg. Smerski se uitsprake oor en ervarings van die persoonlike aard van ervarings van sonde en skuld, staan inderdaad in sterk kontras met die reaksies van sowel die naïewe kapelaan as die verstokte brigadier, ${ }^{3}$ Brigadier Broodryk: "Hy is so verbitterd (...) Hy kan nie aanvaar mense is vry oor wie hy geen seggenskap het nie" (251, maar sien ook 249-250).

Oor die uitbeelding van die skuldmotief het die outeur wel duidelik nagedink. Smerski was nie 'n soldaat toe hy die moorde gepleeg het nie want hy het gedros uit die weermag en het dit uit selfverdediging gedoen, maar hy weet hy kan wettiglik skuldig bevind word as hy voor ' $n$ hof sou gedaag word. Hy sê dan vir Isabel dat dié dreiging soos 'n swaard oor 
hulle sal bly hang. Is daar nie ander soorte skuld ook nie? Natuurlik is daar - ek kan my buurman verraai en dit kan my pla; daardie soort skuld. En dan wat genoem word kollektiewe skuld. Dit is ' $n$ vreemde soort skuld wat twee geslagte verder nie meer skuld is nie. Ek het' $n$ keer die opmerking gehoor dat in na-oorlogse Duitsland die tweede geslag hulle overs kwalik geneem het terwyl die derde geslag oor alles wat plaasgevind het, vere voel. Dit is vir my ' $n$ vreemde skande wat kan verjaar en daarom voel ek' $n$ mens kan nie voorskriftelik omtrent dié belydenis van skuld wees nie. Elkeen moet dit anders hanteer: die een sal gaan bieg, die ander in sak en as verval en nog iemand wil dit deur sy handelinge doen. Miskien het ek dit nie duidelik genoeg gestel nie, maar Smerski is klaarblyklik iemand vir die daad. Sy kollega saam met wie hy die bundel ballingskapverse saamstel, is duidelik 'n bruin man. Natuurlik speel dit wat hulle doen op die SuidAfrikaanse situasie in, maar toe ek met die roman begin werk het, het ek nooit gedink aan die Waarheids- en versoeningskommissie nie. Dit wil nie sê ek is nie verantwoordelik vir wat Smerski daar besluit nie. Op grond van sy ervarings was hy met sy aankoms in Portugal 'n gebroke mens. Hy verloor sy minnares om begryplike redes, hy moes die taal leer, moes studeer; hy kyk na die bedelaar en sien homself in die bedelaar en glo dat een ding wat iy nie durf doen nie is om jouself te bejammer. In sy oë is die bedelaar die slagoffer van sy eie selfbejammering en daarom sê hy selfbejammering kap jou bene en arms af - dit laat jou weerloos (sien 230).

Smerski is kennelik'n gekwelde mens; hy kan nie goed slaap nie, hy droom angsdrome, en dan voel hy wanneer hy met Isabel begin praat - hy begin tog praat as hy agterkom dat hy die meisie in die moeilikheid gaan bring aangesien haar pa' $n$ oud-minister is en sy nog steeds getroud is met 'n soort Portugese kroonprins - skielik verantwoordelik vir haar. Hy voel dan dat sy weens hulle verhouding reg op die inligting het, hoewel hy slegs stuksgewys met die hele verlede voor die dag kom. Hy weet dat hy skuldig is, maar hy is nietemin 'n optimistiese mens. Die werk wat hy doen, hou verband met die hart van taal: die leksikografie en die poësie. Ek het ook die gedig van Celan gekies omdat dit aangrypend spreek van ballingskap en verwyt. Terwyl ek met die roman besig was, het ek iets gelees wat ek nie geweet het nie: Celan se bekende "swart gedig" word elke jaar in die Duitse parlement gelees. ${ }^{4}$ Maar Smerski kies ' $n$ ander gedig, eweneens aangrypend.

\section{Die motief van die kunste}

Verwysings na die woord-en beeldkuns vorm 'n betekenisvolle motief in die roman. Smerski is nie alleen woordeboekmaker nie, maar ook ' $n$ 
(onsuksesvolle) romanskrywer, samesteller van 'n digbundel en iemand wat telkens verwys na die sin van taal en skryf. Isabel se verhaal is in die vorm van 'n dagboek; ander karakters is joernaliste en fotograwe, en die media as sensasiebelustiges, maar ook dokumenteerders, word telkens betrek. Wat is die funksie van hierdie motiewe?

My oogmerk was om ' $n$ toeganklike werk te skryf maar om die vanggat van stereotipes en clichés te vermy. In die teorie word die fotografie dikwels gesien as die ideale medium waardeur die volle waarheid onthul kan word. Elena herken egter in die foto wat Jack haar wys nie die man wat sy ontmoet het nie, maar sy sê tog later aan hom: ek het jou seun ontmoet - die foto het my verwar. Foto's bring jou nie noodwendig by die waarheid uit nie.

Maar ek speel ook met die taalmotief. Die verhaalkarakters lees Portugese vertalings van Duitse gedigte, maar die roman se leser lees dit in Afrikaans. Dit was vir my ' $n$ belangrike element: twee mense wat Portugees met mekaar praat, maar iy hoor dit in Afrikaans. Ek was bewus daarvan dat hier'n talespel ontwikkel. My Portugees is beroerd, maar jy tel gou goed op soos die uitdrukking van "regmaker" (wat eintlik opkikker is): om die ondier dood te maak. ${ }^{5}$ Dit word vir my 'n spel om jou te wys hoe ver jy eintlik van die werklikheid af is - die karakters praat Portugees en jy lees dit in Afrikaans en tog is iy ingetrek daardeur. Die verwysings na die kunste hou ook verband met so 'n soort spel. Ek het half doelbewus Goya gekies. In die "struggle"tyd het jy byna geforseerd gevoel iy moet jou verbind tot Afrika; vandag is dit met' $n$ gevoel van verligting dat iy weet waar sowel Afrika as Europa tekort skiet en jy met vryheid uit albei kulture kan haal en gebruik. Ek werk nie met spesifieke modelle as ek aan 'n roman werk nie; behalwe dalk by kleiner karakters soos Jack - sy houding is gebaseer op iemand wat ek ken, dáár het ek 'n model gehad vir Jack se manier van praat:'n nononsense mens. Ek het nie 'n model gehad vir Isabel nie, maar lees toe ' $n$ boek oor Goya en daarna word sy skildery die model. Ek het gedink dit sal 'n gepaste manier wees om ' $n$ verhouding tussen haar en Smerski te knoop - dis nie 'n cliché-manier nie en ook wonderlik toevallig. Smerski het haar vantevore ontmoet en half geweet sy werk oor Goya, maar sy geheue speel hom parte en hy sê: ek weet nou waar ek jou gesien het. Hy is iemand wat in die skilderkuns belangstel soos iy kan sien in sy woonstel; daar is 'n stoel uit Afrika en die "primitiewe" skilderye uit Europa. Dié belangstelling bind hulle, want sy is ook iemand wat in die skilderkuns belangstel. Die twee skilderye in die huis van Isabel se ouers is ook so 'n belangrike aanknopingspunt. Wat my verder interesseer in die Goya-geskiedenis is dat hierdie skilder tydens die hele ontstuimige geskiedenis van die Napoleontiese tyd in Spanje as hofskilder die verveelde adellikes moet 
skilder. Die illustrasie op die buiteblad verwys ook daarna: die vrou met die mantilla is deel van die fatsoenlike rykes, en Isabel met haar historiese kennis (sy het immers ' $n$ referaat hieroor gelewer) kry'n ander insig in haar werklikheid.

\section{Die skakels in die ketting}

Volgens Miles skep hy nie sy karakters na 'n bepaalde model nie, en kritici van Die Buiteveld het juis op die verskille tussen hierdie nuwe roman en die vorige werke gewys. En tog - die leser bekend met die Miles-oeuvre moet die ooreenkomste tussen Smerski, Okker, Flip Nel en Tumelo John raaksien. Hulle is almal mense met 'n besondere integriteit; gewone mense wie se lewens intens deur die apartheidbestel geraak word en dan ongewone gebeure beleef waaroor hulle skaars beheer het. 'n Polisieman, 'n jong soldaat, 'n onderwyser; mans van wie die ouderdomme - van vroeg in die twintigs tot net duskant veertig - lyk asof dit verskillende fases van dieselfde lewe weergee. In al hierdie romans kan 'n mens die daarstelling van 'n soort Miles-karakter herken; in konkrete terme ' $n$ "boer met' $n$ bakkie en 'n hond", maar lewensbeskoulik ook' $n$ spesifieke soort mens.

Sonja Loots het my juis baie knap bekend gestel 11 November 2003 by Boekhuis, Johannesburg) deur gedeeltes uit van my ou werke aan te haal en so te wys waar kom Smerski vandaan. Maar intussen het ek my voorgeneem om in die volgende ding waaraan ek werk nie weer die woord "skuldig" te laat opduik nie. Ek kan dit ook herlei na myself wanneer ek dink aan my eie reaksies op die apartheidsonreg. Destyds het ons ons die vraag afgevra: wat kan ek hieraan dóén? Ek meen dit is ' $n$ beter vraag as: ek voel skuldig, hoe kan ek bely? Onlangs het ek Martin Meredith se lewensverhaal van Bram Fischer gelees (Fischer's Choice, 2002). Wat Fischer sonder twyfel uitstekend gedoen het, was juis sy werk as regsman. Hy kon dit regkry dat mense nie gehang is nie. Maar die oomblik toe hy gaan onderduik, toe verloor sy Beweging belangstelling in hom. Hy het probeer om selle te stig en mens kon begryp hoekom hy dit gedoen het. Dit was 'n soort wanhoopsdaad. Daar was 'n motorongeluk en hy het verantwoordelik gevoel vir sy vrou se dood. Hy het bestuur, uitgeswaai vir ' $n$ bees en die voertuig het in die water geval. Hy en hulle vriendin kon deur die venster vitkom, maar sy vrou het geslaap agter en is vasgekeer in die kar. Hy het skuldig gevoel, en wou daarom iets meer doen ... Ek dwaal nou af, maar ek voel vandag tog dit was die regte ding om iets te doen op die terrein waarvan jy die een en ander weet. Hoe gering dan ook. Dit was vir my destyds van veel meer waarde om by Taurus (die private uitgewery 
gestig deur Ampie Coetzee, Ernst Lindenberg en Miles) betrokke te wees as om een of ander fabriek te gaan opblaas. Ek het reeds die sondebegrip agtergelaat, nou ook die getorring aan skuld. Ek sou eerder wil fokus op die dade self ...

Ja, ek dink daardie karakters (Okker, Flip Nel, Tumelo John, Smerski) verteenwoordig 'n soort ideaalfiguur, almal het iets gedoen; ek voel tevrede daarmee dat' $n$ mens dit kon sê.

Maar, op 'n ligter trant is die verhouding tussen die boer en sy hond ook'n skakel tussen al hierdie romankarakters! Miles gee spottend toe dat hy "eintlik 'n hondemens" is. Hy het eendag tot die verbasing van 'n groep honneurstudente in dié trant ' $n$ opmerking oor Elsa Joubert se Die reise van Isobelle gemaak. "Daar is mos' $n$ toneel waar sy soveel aandag gee aan die jong seuntiie wat grootword, wat in die tuin speel, maar nêrens ooit is daar ' $n$ troeteldier nie - ' $n$ kat of ' $n$ hond nie - en dit is so algemeen by ons mense om ' $n$ troeteldier te hê..."

\section{Die rol van die vrou}

Die rol van die vrou as (ek-)verteller in Die Buiteveld bring wel 'n heeltemal nuwe element in die skryfwerk van Miles. Die sukses van hierdie keuse is deur verskillende lesers viteenlopend beoordeel. Miles se motivering is, onder andere, dat hy moeg geword het vir die deurlopende fokus op Smerski. Alles is op sý ervarings gefokus en hy het eintlik 'n baie ontoeganklike karakter. Ek sien hom egter nie as ' $n$ selfsugtige mens nie, dalk nogal ontoeganklik. Een toneel wat nou by my opkom, is waar hy in Maputo alleen in sy hotelkamer sit en hy skakel die lugreëling af en dan hoor hy die geluide van ander mense en raak hy bewus van hulle teenwoordigheid in die kamer. Dis openbarend van sy verhouding met mense. Maar hoekom ek daardie "drastiese" stap gedoen het om na die vrou as verteller oor te skakel, is ook omdat ek onthou hoe iemand destyds met Kroniek uit die doofpot teenoor my gesê dat' $n$ wit mens nie deur die oë van 'n swart man kan kyk nie. Dit is soos die argument van: kan jy oor 'n Rus skryf? 'n Mens kan op die ou end antwoord: maar ek kan nie eers oor myself skryf nie.

Dit is tog opvallend dat vrove ' $n$ baie groter rol speel in hierdie roman as in die vorige Mileswerke, hoewel hy self verwys na Jenny in Okker bestel twee toebroodjies en Otti in Blaaskans as belangrike figure. Dit is Theresa wat die oorsaak is dat Smerski bly lewe, dat hy nuut kon begin, terwyl Isabel die moontlikheid bied dat hy uit die gevangenisskap of ballingskap van eensaamheid kan ontsnap.

Hulle ís ook albei sterk vrove - veral Theresa - en dit is hoe ek die vrou graag wil sien. Isabel bring die potensiaal van 'n sinvolle verhouding. Ek 
wou dit spesifiek ook so hê dat hierdie ruimte van geborgenheid duur, dat die verhouding voortgaan, en dit is wat dit' $n$ hoopvolle einde maak, ten spyte daarvan dat hy miskien binne die groter raamwerk van die gang van die geskiedenis ' $n$ pessimistiese siening het. Maar dit is ook vir mý lewensbelangrik - ons weet die dood wag, maar as jy in die môre opstaan dink iy nie pessimisties daaraan dat ek eendag doodgaan nie. Jy staan op, iy werk en iy dóén.

Ook Elena speel 'n beduidende rol. In my agterkop is Elena so ' $n$ bietjie fataal - sy is die laaste klimaks: die dood. Sy is eintlik die agent van die dood. Dit is waarskynlik waarom sy nie werklik op die lughawe is nie. Hy dínk hy sien haar maar dit is nie sy nie. "Nee, sy is nie daar nie, maar hy vermoed haar teenwoordigheid, sy is ' $n$ agent van die dood. Ek wil dit nie eintlik so stel nie, want ek werk nie só met simbole nie. Dit is net ' $n$ metaforiese raakpunt, maar' $n$ mens sien tog hoe speel sy met haar horlosie (wat sy om haar nek dra). Sy word ook duidelik geassosieer met Jack se dood. Maar sy is nog ' $n$ vrou ook - sy is nie net ' $n$ simbool nie. Sy is ook die hele tyd besig om Smerski aan sy skuld te herinner. En vir hom is dit nie 'n aangename manier om 'n gesprek te begin nie. Maar hy sê daar in die begin ook vir haar as sy oor die WVK praat: dit is 'n noodsaaklike politieke daad, en hy gaan ook vir die oud-kapelaan sê dit is tog veral vir toonaangewende mense bedoel-mense wat in die meesternarratief speel. Smerski kan nie; hy kan dit nie doen nie. Dit is nie dat hy dit afskryf nie, maar hy is nie iemand vir die ritueel nie en ek dink daar is ruimte vir so 'n standpunt.

Maar ek kan iets anders noem rondom die rol van die vrou. Ek was in Kroniek vit die doofpot met die vitbeelding van Tumelo John geweldig aan bande gelê om sensualiteit in te bring. Om 'n poëtiese intimiteit weer te gee, want ek het gevoel dit is nie die plek daarvoor nie. Uit my agtergrondstudie van die mens wat pa gestaan het vir Tumelo John het ek wel 'n suggestie opgetel van so iets tydens sy besoek aan Zimbabwe saam met sy skoonpa. Maar dit was te vaag en ek wou die feite van die lêer eerbiedig tot die laaste een toe. Ek wou niks ignoreer nie, maar het gedink daardie suggestie van sensualiteit pas nie. Met Die Buiteveld wou ek my nie weer so aan bande lê nie.

\section{Waar kom die titel vandaan?}

Die meeste lesers is sekerlik deur die titel geïntrigreer - waarna sou "Die Buiteveld" verwys? In die loop van die verhaal word die begrip wel verskeie male opgehaal. Met Isabel se verjaarsdag in die eensame hoogland van die Terra Fria nooi hy haar vir 'n spesiale ete in hierdie "hart van die 
buiteveld" (109). In Suid-Afrika is dit Boesmanland wat hy die "buiteveld" noem en waarna hy haar wil neem. Maar albei besef ook die emosionele waarde van hierdie begrip, wanneer Isabel in die laaste paragrawe opmerk: "Die Buiteveld, sê iy? Smerski, iy's lank reeds daar" (268). Die Portugese retornados wat terugkeer na die moederland, die gedigte van ballingskap, maar ook die slotwoorde wat impliseer dat die mens altyd op reis is en nooit finaal tuiskom nie, sluit by hierdie motief aan.

Isabel het natuurlik soveel insig in hom dat sy kan sê die "buiteveld" is eintlik' $n$ geestelike ruimte - hy is altyd daar. Ek het die titel gekies omdat dit in die plaaswêreld op afstand dui, maar dit is nog steeds deel van die plaas. Dis nie dat iy jou rug draai op die werf nie; Die buiteveld is nou wel nie die sentrum van boerdery nie, maar dit is ' $n$ noodsaaklike deel van die plaas en is nog binne die grense daarvan. Ek het natuurlik die sportverwysing ook in gedagte gehou. In krieket veral is die buiteveld belangrik. Die een wat daar speel is 'n baie belangrike veldwerker want hy keer die harde balle en hy moet goed kan ingooi. Hy staan op die rand - op die grens. Nou is dit so interessant; die HAT het ' $n$ ander betekenis daarvoor by gholf aangegee. In die gholfbetekenis is dit anderkant die grens - daar waar iy nié mag speel nie. Daar waar die bal buite spel is. Ek het skielik die ander dag daaraan gedink dat sommige kritici van Smerski 'n gholfspeler sal wil maak terwyl ander hom as ' $n$ krieketspeler sal aanvaar. Nou het sommige hom reeds beoordeel as ' $n$ speler wat hom met die onaanvaarbare ophou, anderkant die sanksioneerbare.

Daar is ook die episode waar Smerski en Isabel hulle vroegste herinneringe van 'n bepaalde omgewing vitruil (101-102). Waar sy die triomfantlike verbymars van Spinola se soldate in die strate van Lissabon onthou, sien Smerski die beeld van 'n vrou wat help om die skape wat van ver uit die buiteveld kom, kraal toe te bring en hulle ook tel. Ek het gedink aan sy ma se herkoms, sy ma se plaas. Ek wou hê dat die leser wat iets van boerdery weet, besef dat dit onmoontlik nie in Mosambiek kan wees nie - hulle boer nie met skape nie. Isabel se pa hoor later die storie en begryp dan dat iets nie inpas nie, en daarom het ek die skape daar genoem. Die toneel is ' $n$ weergawe van iets wat ek eendag opgeteken het. Ek het' $n$ afspraak met iemand gehad en toe sê die mense vir my hulle is besig om die skape aan te jaag en daardie hele toneel van die vrou wat die skape so tel by die hek en die boer wat saam met die honde bontspring, het by my opgekom. Die belangrike funksie daarvan lê in die betekenis van die skape wat van die buiteveld af inkom, dat dít Smerski se eerste herinnering is, en dan ook die funksie ten opsigte van die spanning in die verhaal: dat so 'n toneel nie moontlik is in Mosambiek nie. 


\section{Toekoms en toeval}

Op die vraag of hy reeds weer besig is met'n nuwe roman, antwoord Miles: "Die volgende boek het reeds sy titel. Ek moet sê is ek' $n$ bietjie op so 'n "high" - gemotiveerd. Ek het so 'n mooi vitdrukking gehoor wat 'n jong meisie vir haar ma gesê het, ek ken eintlik haar ma, sy het gesê, "as long as it blows your hair back"! En dis hoe ek nou voel". Dat hierdie uitdrukking herinner aan die foto wat Jack geneem het van die jong meisie op die motorfiets in Namibië (sien 222), lei die gesprek weer terug na die skuldmotief. Ek is bly iy noem dit (die meisie op die motorfiets). Ek dink Willie Burger het in sy kritiek op die roman spesifiek gevra: wat van die slagoffer? Dit laat my vra: wie is almal slagoffers? 'n Mens kan 'n slagoffer herken omdat iy dit self antisipeer, en Smerski self het soveel elemente van die slagoffer in hom. Moet die slagoffer dan die bruin man of die swart man wees? Jack praat ook hieroor by die tentoonstelling, en dit is die burgemeester wat sê sy (die meisie op die motorfiets) lyk soos ' $n$ teken van swart hoop. Sy laat nie van haar' $n$ slagoffer maak nie, en daar is respek vir die slagoffers van kolonialisme. Dit is nie 'n hooftema nie - ek weet dit - en ek voel dit is nie dat Smerski dit alles wegstoot nie.

John Miles is tevrede dat "die boek sê wat hy wou gesê het". 'n Mens moet so oppas dat jy nie dinge te duidelik uitspel nie. Soos die verwysing na die vlieë, wanneer hy die kongres bywoon gee hy mos so 'n opsomming van Sartre se Vliee. ${ }^{6}$ Dit is ook iets vreemds wat my oorgekom het terwyl ek aan die huis bou was op die plaas. Ek moes gou speel, die winter was aan die kom, wanneer dit baie, baie nat word. Vroegoggend is dit reeds koud. Ek dra toe ' $n$ baadjie wat op ' $n$ stadium respektabel was, waarin ek in die winter sou kon klasgee. Ek voel in my sak na'n merkpen en kry in plaas daarvan 'n opsomming van twee of drie boeke wat as agtergrond gebruik is by lesings oor die Sestigers. Daar is toe 'n opsomming van Vlieë ... kan iy glo! En toe weet ek dat ek dit gaan gebruik. Met Smerski se besoek aan die kapelaan vra dié se vrou, Kirstie, mos vir Smerski - wat sy toe ken as JJ - of hy agtergekom het die vlieë pla so erg (sien 264). Ek wóú eers skryf dat Smerski toe terugdink aan Sartre se werk, maar toe besef ek ek kán nie want dan is dit te helder en direk. Die wat die verband nie sien nie moet dit op'n ander manier kry. Ek dink tog ek het gesê wat ek wou sê. Jy weet, 'n mens loop en spook hierdie goed uit en dit was vir my wonderlik die dag toe ek in mý kop kry - toe ek dit in die bóék se kop wou inwerk - dat daar ' $n$ verband is tussen die WVK en Big Brother (die "realiteits"-televisieprogram). Dit is ook 'n skouspel en 'n valstrik; ' $n$ booby trap - iy los nie probleme so op nie. Smerski sê mos ook aan die oud-kapelaan dat ' $n$ openbare skouspel ' $n$ booby trap vir hom is (sien 266). Op die manier 
belig die een situasie die ander. As hierdie twee mense kaal vit die stort kom, lyk hulle skielik so verleë (Big Brother, sien 252) en dan dink Smerski: dit kom daarvan as jy jou private lewe as skouspel aanbied. Dit was ook vir my'n les. As hy vir Isabel op die lughawe ontmoet, moet ek nie daarvan 'n skouspel maak nie. Hulle is lief vir mekaar en die hartstog kan maar vlug gegee word.

Die anekdote rondom die bron vir die "vlieë"-motief bring die veelseggende rol van toeval en noodlot ter sprake. 'n Leser sou selfs kon dink daardie rol is in Die Buiteveld te ver gevoer. In die eerste 10 bladsye reeds word byna al die karakters met mekaar verbind by wyse van toevallige opmerkings. Smerski vertel aan Isabel dat sy ontsnapping en oorlewing aan toeval te danke was; haar Pa meen dat dit onmoontlik vir een mens is om deur soveel toeval omring te word; Smerski se mislukte roman is deur keurders afgewys omdat dit te veel op toeval gebou was.

Ons het die neiging om toeval uit te skakel of te onderskat want die veronderstelde plan staan voorop. Sekerlik staan baie voorvalle in die verhaal op die rand van ongeloofwaardigheid. Maar ek dink, veral in ons postmoderne tyd weer, waar die pop-roman en die strokiesprent so oorbebekend is, kan dit nie vir my leser met ' $n$ postmoderne ervaring ' $n$ probleem wees nie. Toevallig ontmoet Smerski nou hierdie Duitsers en dis hoekom die verhaal so wegspring - daar is soveel ander rigtings waarin dit van hier kon ontwikkel... Jy sou nou dink dit is toevallig, maar met my koms hierheen, na Pretoria vir die boekbekendstelling, was dit nogal 'n gejaag met die inpas van dinge by die Kaapse lughawe dat ek skoon vergeet het passasiers mag nie iets soos ' $n$ sakmes by hulle hê nie. Ek is iemand wat 'n knipmes dra en toe ek daar inloop, wil hulle my mes konfiskeer. Ek dink toe 'nee, my mes is nie vir jou nie, meneer; iy sit seker daar met' $n$ mandjie vol van die goed'. Ek gaan toe uit en vra die bestuurder van 'n boekwinkel hy moet die mes vir my hou. Hy wou eers nie en ek dog toe hy moet maar daarmee maak wat hy wil, maar ek gaan terugkom met die hoop dat dit nog daar is. So, Smerski agtervolg my. Is dit nie toevallig nie? Hy word geken aan sy mes, en hier word ek voorgekeer omdat ek die onskuldigste van messe dra.

Die Afrikaanse roman aan die begin van 2004 verwoord ' $n$ era van gelyktydige afskeid, oorgang en voortgang. Hierdie meerstemmigheid resoneer die sterkste in werke wat bepaalde tendense nie resepmatigof selfs glad nie - reflekteer nie, maar wat juis op innoverende en insiggewende wyse'n eie stem laat klink. In Die Buiteveld word dit duidelik gestel: die tyd het aangebreek om nuwe ervarings te beskryf. 


\section{Aantekeninge}

1 Onderhoud gevoer met John Miles in Pretoria op 13 November 2003. Die gesprek is in 'n ander lettertipe geset. Miles se uitsprake en besinnings word in gewone romeinse skrif geset, en waar woordeliks aangehaal, tussen aanhalingstekens geplaas. Die dele in kursief is die bydrae van die onderhoudvoerder.

2. "dat alles aan die kus van Suid-Afrika vir hulle bekend voorkom, alles behalwe die mense; die blaf van die honde klink net soos dié in Portugal, die horinglose os wat hulle naby Mosselbaai ruil om te slag, smaak so goed soos dié in Alentejo. En die hoenders is gewoon hoenders soos die kormorante, meeue en tortelduiwe. Die pikkewyn is wel vreemd, 'n voël wat nie kan vlieg nie. Maar die mense is vir hom heeltemal anders, hulle is blas en dra velle" (103).

3. Smerski: "Maar vir skuld en boetedoening is jy op jouself aangewese. Die ewige gebieg en jammerlike belydenis is vir die swakkeling" (45, maar sien ook byvoorbeeld 65, 252 en 266).

Kapelaan Kobus de Wet: "ek was vir twee jaar na die WVK gesekondeer as kommissaris (...) Ek het gesien wat dit vir mense beteken om daaroor te getuig. Ek het die hele proses meegemaak, en is ek nie dankbaar nie!" (264, maar sien ook 265 en 266).

4. Sien 80. Miles verwys waarskynlik na Paul Celan se "Todesfuge".

5. “'n Opkikker?' vra die toonbankkelner. (In Portugees, letterlik: Wil jy die Ondier doodmaak?)" (25). Let op die ingebedde taalaanwysings.

6. “Hy lees die opmerkings oor Sartre se Vlieë: Orestes keer terug na sy plek van herkoms,'n gemeenskap vasgevang deur berou en boetedoening waar die inwoners mekaar gedurig aan hulle skuld herinner, vol wroeging en behep met die verlede. Openbare belydenis is die nasionale tydverdryf. Die swart vlieë wat die plek teister, is roudraers, agente van 'n god van die dood en onvryheid ..." (234-235).

\section{Bronnelys}

Hambidge, Joan. 2004. Afrikaanse letterkunde se toekoms is duister. Rapport, 4 Januarie, 13.

Kannemeyer, J.C. 1988. Die Afrikaanse literatuur 1652-1987. Kaapstad: Academica.

Roodt, D.F. 1988. Oor die koloniale drempel heen. SA literêre diskoerse van die afgelope 30 jaar. Restant 16(1): $37-64$.

Roodt, Dan. 2004. Die Afrikaanse boek kán weer bloei. Rapport, 11 Januarie, 17.

Roos, Henriette. 1998. Die Afrikaanse prosa van die twintigste eeu. In Van Coller H.P. (red.) Perspektief en profiel. 'n Afrikaanse literatuurgeskiedenis. Deel 1. Pretoria: J.L.Van Schaik, 21-117. 